\title{
Expression of Concern: Adaptation of ANFIS model to assess thermal comfort of an urban square in moderate and dry climate
}

\author{
Shahab Kariminia ${ }^{1} \cdot$ Shervin Motamedi $^{2,3} \cdot$ Shahaboddin Shamshirband $^{4} \cdot$ Dalibor Petković $^{5}$. \\ Chandrabhushan Roy ${ }^{2} \cdot$ Roslan Hashim ${ }^{2,3}$
}

Published online: 29 May 2019

(C) Springer-Verlag GmbH Germany, part of Springer Nature 2019

Expression of Concern: Stoch Environ Res Risk Assess (2016) 30:1189-1203 https://doi.org/10.1007/s00477-015-1116-3

The Editor-in-Chief of Stochastic Environmental Research and Risk Assessment is issuing an editorial expression of concern for article (Kariminia et al. 2016a) to alert readers that the authors suggested peer reviewers whose identity was not possible to verify. This article contains overlap with the following articles (amongst others) (Petković and Shamshirband 2015; Kariminia et al. 2016b). The authors do not agree to this expression of concern.

\section{References}

Kariminia S, Motamedi S, Shamshirband S et al (2016a) Stoch Environ Res Risk Assess 30:1189. https://doi.org/10.1007/ s00477-015-1116-3

Kariminia S, Motamedi S, Shamshirband S et al (2016b) Theor Appl Climatol 124:991. https://doi.org/10.1007/s00704-015-1462-6

Petković D, Shamshirband S (2015) Int J Electr Power Energy Syst 69:98-103. https://doi.org/10.1016/j.ijepes.2014.12.086

Publisher's Note Springer Nature remains neutral with regard to jurisdictional claims in published maps and institutional affiliations.

The original article can be found online at https:// doi.org/10.1007/s00477-015-1116-3.

Shervin Motamedi shervin.motamedi@gmail.com

$\triangle$ Shahaboddin Shamshirband shamshirband1396@gmail.com

1 Department of Architecture, Faculty of Art, Architecture and Urban Planning, Najafabad Branch, Islamic Azad University, Najafabad, Isfahan, Iran

2 Department of Civil Engineering, Faculty of Engineering, University of Malaya, 50603 Kuala Lumpur, Malaysia

3 Institute of Ocean and Earth Sciences, University of Malaya, 50603 Kuala Lumpur, Malaysia

4 Department of Computer System and Technology, Faculty of Computer Science and Information Technology, University of Malaya, 50603 Kuala Lumpur, Malaysia

5 Department for Mechatronics and Control, Faculty of Mechanical Engineering, University of Niš, Aleksandra Medvedeva 14, 18000 Niš, Serbia 